\title{
An assessment of rate-pegging in New South Wales local government
}

\section{Commonwealth Journal of Local Governance \\ Issue 6: July 2010 \\ http://epress.lib.uts.edu.au/ojs/index.php/cjlg}

\section{Brian Dollery \\ Centre for Local Government, University of New England}

\section{Albert Wijeweera}

Petroleum Institute, Abu Dhabi
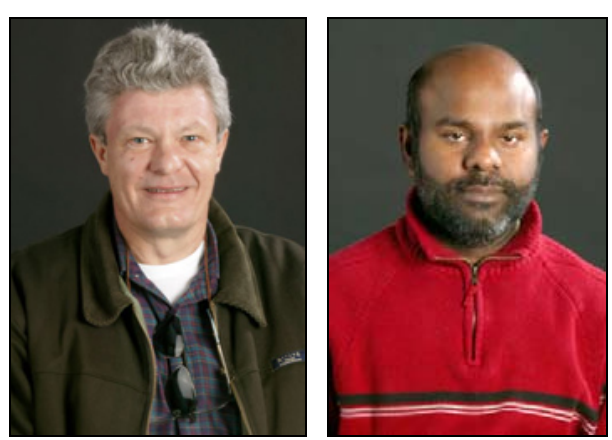

\begin{abstract}
Rate-pegging has been in place in NSW for more than thirty years with broad support from all sides of politics. However, in late 2008 the NSW Government commissioned IPART to report on the adequacy of rate-pegging. IPART produced a Draft Report and then a Final Report, which has not yet been released by the NSW Government. Nevertheless, the NSW Government has made some changes to local government finance by way of capping developer charges, allowing IPART to make annual rate-pegging determinations, and enabling IPART to consider special variations in rate-pegging. Against this background, this paper considers the principles and practice of rate-pegging in NSW, the rationale for rate-pegging and counter-arguments on its desirability, as well as its economic effects on NSW local government finance relative to other Australian local government jurisdictions.
\end{abstract}

\section{Keywords}

Council Rates, Local Government, Rate-Pegging. 


\section{Introduction}

New South Wales (NSW) is alone amongst Australian states in employing a policy of rate-pegging designed to limit increases in property taxes that can be levied by local councils in that state. ${ }^{1}$ In essence, the term 'rate-pegging' refers to the imposition of state government determined upper annual bounds on the annual rate of increase in property taxes levied by municipalities. This policy has been an ongoing source of bitter controversy in NSW itself and the cause of much bemusement in the broader Australasian local government community (Dollery, Crase and Johnson 2006). While NSW had employed a form of rate-pegging between 1901 and 1952, which was discontinued due to its 'impracticality' (NSW Local Government and Shires Association 2008:16), the genesis of the modern method of rate-pegging may be found in the 1976 state election campaign, where rapid increase in rates had become the subject of political controversy. Under the Local Government (Rating) Further Amendment Bill, an interim type system of rate-pegging was re-introduced by the victorious Wran Labor Government in 1977 and further refined into its contemporary form in 1978. The timing of the introduction of rate-pegging legislation into the NSW Parliament should be seen against the historical backdrop of economic developments in NSW in the 1970s; over the period 1973 to 1976, rates had increased on average by 188 per cent, largely as a consequence of increased local government expenditure, whereas average weekly earnings over the same period rose by 75 per cent and the rate of inflation was 56 per cent (Johnson 2001:5). ${ }^{2}$

While the mechanics of the rate-pegging process have been adjusted periodically, the basic principle has remained unchanged to the present day. However, on 27 October 2008, (then) NSW Premier Nathan Rees announced to the annual New South Wales Local Government Association conference that the NSW government had given serious thought to removing rate pegging. This followed an earlier instruction to the NSW Independent Pricing and Regulatory Tribunal (IPART) in May 2008 to investigate the operation of rate-pegging and report on its findings. In July 2009, IPART released a draft Review of the Revenue Framework for Local Government. This Draft Report proposed two alternative approaches for a revised system: Option A would retain rate-pegging for

\footnotetext{
1 An exception resides in the fact that the Northern Territory joined NSW in imposing rate-pegging for a transitional three-year period beginning 2008 while extensive structural reform was put in place (Productivity Commission, 2008, p.97).

${ }^{2}$ Increases in rates in other Australian local government jurisdictions over the same period were substantially lower than in NSW (Radbone and Robins, 1980).
} 
all councils, but link it to a new local government cost index and establish a 'medium term' cap on rates to allow for some revenue certainty. Option B would add to Option A: under Option B councils which demonstrated sound financial performance (as measured in accounting terms) would be exempted from rate-pegging altogether for periods up to four years.

After a period of public submissions on the Draft Report, IPART handed a Final Report of Review of the Revenue Framework for Local Government to the NSW Government in December 2009. As at July 2010, the NSW Government had still not released the Final Report to the public, nor had it responded formally to the Final Report of the Review of the Revenue Framework for Local Government. However, as part of the 2010/11 NSW budgetary process, the NSW Premier Kristina Kenneally announced 'sweeping changes to local government charges on new housing development' which involved some modification in the manner in which rate-pegging would be applied in NSW local government in future (Keneally 2010). As part of its $\$ 44$ million Comprehensive Housing Supply Strategy, aimed at securing 'additional land releases, lower levies and faster planning decisions', the NSW Government set out the following measures: (a) A 'hard cap' of \$20,000 per lot for council developer charges, known as Section 94 contributions in NSW, imposed on new developments, and (b) a constraint on council Section 94 charges to be limited to 'essential infrastructure' which was 'necessary for the development to happen', like road works and stormwater management. Since (a) and (b) would inevitably intensify financial distress in local government, the NSW Government recognised that they would place upward pressure on rate-peg variation claims from local authorities. As a consequence, it retained rate-pegging, but it modified the process of rate-pegging. In the first place, the NSW Government transferred the determination of the rate-peg to IPART, which would devise a new Local Government Cost Index to employ in setting the annual rate-peg. Secondly, IPART was also placed in charge of deciding 'special rate variation requests' by councils, as well as 'variations for essential and community infrastructure’.

These requests, through which councils sought permission to levy rate above the ratepeg, had hitherto been considered by the Minister for Local Government directly. No further detail has been forthcoming from the NSW Government on the mechanics of the new process and it remains to be seen how it will work in practice. 
Without getting involved in the minutiae of the two IPART recommendations, which have yet to be accepted or rejected, or the proposed new method of IPART implementing the rate-pegging process, it thus seems an opportune time to consider the nature of ratepegging, the arguments surrounding its desirability, and its economic effects on NSW local government. This forms the main aim of the present paper.

The need for a satisfactory and stable rate-setting regime in NSW local government has been heightened by the Local Government Amendment (Planning and Reporting) Act 2009, which introduced an Integrated Planning and Reporting (IPR) framework. From the financial year 2010/11 onwards, the IPR framework will oblige local councils to prepare a long-term (minimum 10-year) Community Strategic Plan, a 4-year Delivery Program to implement that plan, plus annual Operational Plans and Annual Reports. The planning time horizon for local government has thus been substantially extended and consequently councils will require greater certainty on future rate increases. This makes debate on the current system of setting rates in NSW especially relevant.

The remainder of this paper is divided into five main parts. Section 2 provides a synoptic description of the principles and practice of rate-pegging. Section 3 considers the rationale for rate-pegging and various arguments on this question. Section 4 seeks to evaluate the impact of rate-pegging on trends in rates in NSW relative to other Australian state local government jurisdictions. Section 5 provides a synoptic description of various suggestions which have been proposed for improving the rate-setting system in NSW, including those contained in the IPART Draft Report. The paper ends with some brief concluding remarks in section 6.2 .

\section{Principles and Practice of NSW Rate-Pegging}

In terms of the Local Government Act 1993, NSW local authorities have six main sources of revenue: rates, charges, fees, grants, borrowings, and investments. With respect to income from property, under Section 493 of the Local Government Act 1993 local councils calculate and distribute rates among four defined categories of rateable properties in their respective local jurisdictions; farmland, residential, mining and business. Section 492 of the Act makes provision for two types of rates: ordinary rates and special rates. Section 494 of the Act stipulates that every council must strike and 
levy an ordinary rate each year on all rateable land within its jurisdiction. By contrast, a local council can exercise discretion on whether or not to levy a special rate under Section 495 of the Act. Special rates are aimed at the finance of particular projects, such as specified local infrastructure, but must be applied to all ratepayers if the project will benefit the entire local government area (Department of Local Government 2007).

For each category of property, rates can be calculated in one of three ways: Entirely on the land value of the property (calculated as an amount per dollar of unimproved land value); on a combination of the land value of the property and a fixed amount per property; and entirely on the land value, but subject to a minimum amount. Land values are set by the Valuer General at the Department of Lands under the Valuation of Land Act 1916 every four years (Department of Local Government, 2007).

Part 2 of Chapter 15 of the Local Government Act 1993 allows the relevant Minister to impose limits inter alia on a council's 'general income'. ${ }^{3}$ With respect to the mechanics of rate-pegging, the NSW government sets a ceiling on the total amount of income that each council can raise from its rates and charges on land. This limit is termed the 'ratepeg percentage' and it is prescribed prior to each fiscal year by the Minister for Local Government. As a consequence of rate pegging, a given council's overall rates revenue cannot increase by more than the percentage increase approved by the Minister. Indeed, even if land values in a local government area rise in aggregate, local councils may have to reduce or otherwise adjust the amounts levied per dollar so that total revenue does not increase by more than the percentage increase stipulated by the Minister (Department of Local Government 2007).

In terms of the Local Government Act 1993, 'general income’ does not include various rates and charges, including rates on water supply and sewerage, annual charges for waste management and storm water management services. Other sources of revenue are

\footnotetext{
${ }^{3}$ In addition to rate-pegging, other budgetary and legislative constraints affect the ability of local councils to set rates in NSW. These also operate in other Australian local government jurisdictions. They include the land and property valuation methods stipulated by state governments, constraints on the ability of local authorities to impose differential rates on different categories of ratepayer, exemptions made for various classes of ratepayers (sometimes offset by reciprocal tax arrangements), and concessions that must be applied to certain categories of ratepayer (sometimes offset by reimbursements).
} 
also not covered under 'general income', such as user charges, interest, grants, developer contributions, donations, and other forms of revenue, like fines and business activities. As we have seen, councils can apply to the Minister for Local Government for permission to increase their general income by more than the rate-peg limit, a process which has now been transferred to IPART. This is called a special variation application. Guidelines for such applications have thus far been issued each year by the Department of Local Government, and councils applied for a special variation for one year only or for several years. A council had to include details of its intention to apply for a special variation in its draft management (corporate) plan and consider any submissions received from the public. If approved, the Minister specified the percentage by which the council could increase its general income, as well as the period of time over which rates may exceed the rate-peg. Whether the new IPART process follows this path remains to be seen.

To date, the process of rate-pegging has involved an annual limit on rate increases, typically set in March each year. In principle, 'this percentage reflects the projected annual increase in costs that a typical council delivering services at levels comparable to the previous year is likely to incur this year' (IPART 2008:48). Following this announcement, individual councils submitted requests for a special variation to the Minister for Local Government, who made a final determination on each submission by June. This enabled local councils to strike their rates to take effect by 1 July of each financial year.

Given the proposition that the rate-peg percentage is supposed to reflect the 'projected annual increase in costs' faced by councils, it is interesting to compare the rate-peg with the Consumer Price Index (CPI) over the past ten years. Figure 1 compares the annual rate peg with the CPI over the fiscal years 1998/99 to 2008/09: 
Figure 1: Annual Rate Peg Percentage and Change in CPI, 1998/99 to 2008/09

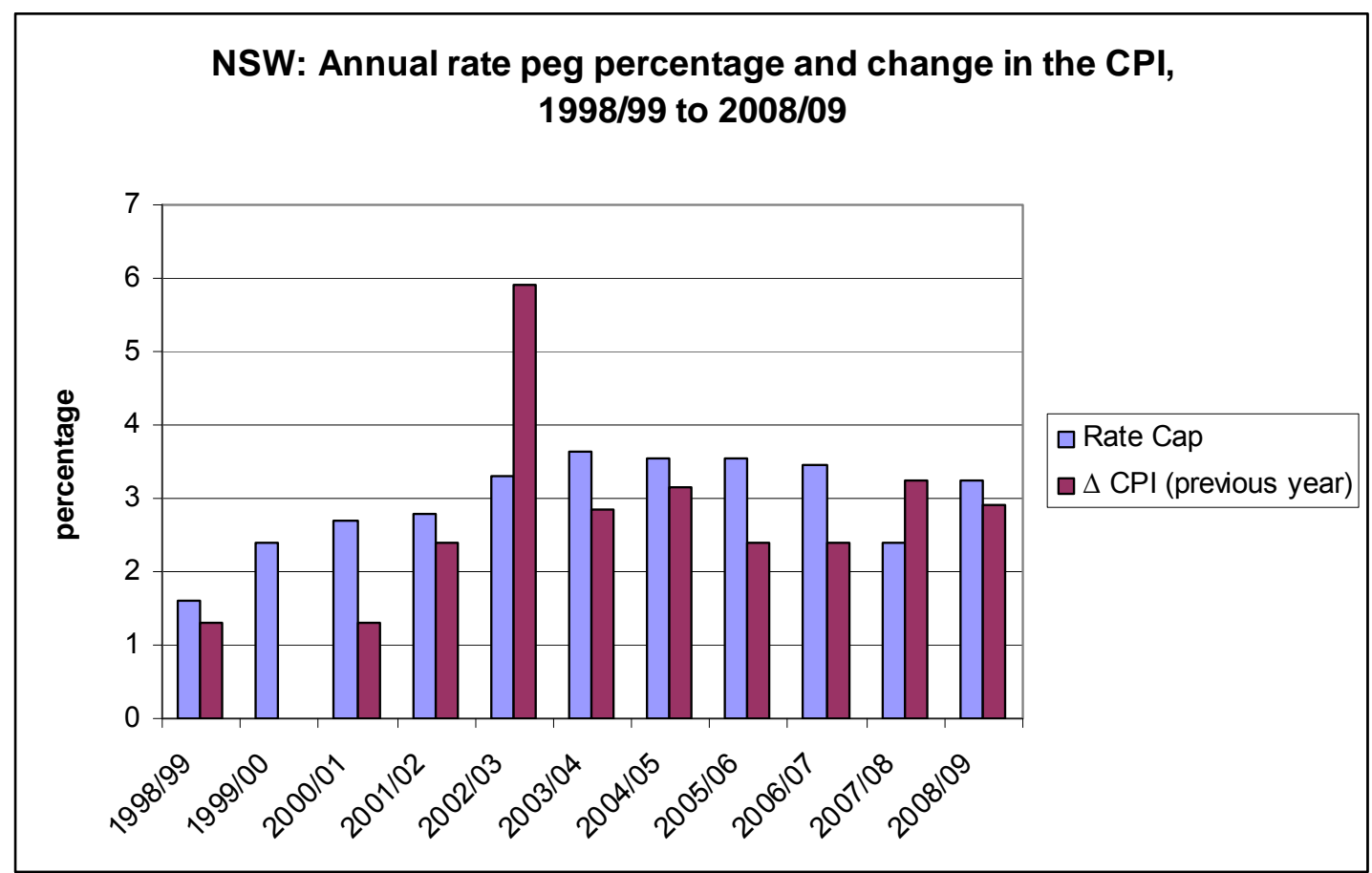

Source: Amended Table 7.1 (IPART, 2008, p.48).

The information contained in Table 1 indicates that, in general, the rate cap exceeded the change in the CPI over the previous financial year; this is true for all years, except 2002/03 and 2007/08. It should be noted that the CPI for 2001/02 contained in the 2002/03 column in Table 1 reflects the impact of the introduction of the new

General Sales Tax (GST) on goods and services of 10 percent by the federal government, making it an unusual year. A second feature of the data contained in Table 1 is that, by way of a general trend, the rate cap and the CPI track each other closely. Finally, it should be stressed that the CPI is a measure of the rate of increase of a given basket of goods and services, weighted to reflect Australian consumption patterns, rather than a measure of production costs. It is thus not a good measure of the rate of increase in the costs faced by councils.

\section{Rationale for Rate-Pegging}

Rate-pegging represents a sub-set of a larger category of public sector regulation dealing with state-imposed limitations on the expenditure and taxation by local government, including property taxation (see, for example, Temple 1996 for a synoptic review of this 
literature). This kind of regulation has given birth to a theoretical and empirical literature which has an overwhelming American institutional bias. State-wide limitations on local taxes, fees and charges, including property taxes, are comparatively common in the United States and often put to electorates in the form of referenda (see, for instance, Figlio and O’Sullivan 2001). However, little is known about either the effects of explicit tax and expenditure constraints on local government or the determinants of voter support for fiscal limitations. In common with earlier work, Temple (1996) found evidence which suggested that state-wide limits on property taxes induced a relatively larger reduction in local services than local administration. By contrast, Vigdor (2004) has argued that tax limitations have succeeded because they allowed voters to lower tax rates in communities other than their own where they hold property, invest or work, but have no vote. Unfortunately, this American literature has little bearing on rate-pegging in NSW since there is no provision for referenda on local taxes. Moreover, the significant differences between Australian and American local government, not least the much narrower range of functions in Australian local government, render most of this literature irrelevant to the NSW case.

The economic rationale for rate-pegging derives from the normative prescriptions of standard economic theory: local government enjoys a monopoly in the provision of essential local services. Accordingly, like all other monopoly providers, it will provide these services at excessive prices and/or inefficiently and thus warrants regulation by higher tiers of government to ensure efficient and equitable outcomes (Bailey 1999). However, it is important to immediately add the caveat that regulation must be carefully applied since bad regulation can make matters worse than no regulation at all (Hillman 2005). The validity of this general proposition is recognised in the NSW debate over rate-pegging (see, for example, NSW Treasury 2008).

With respect to economic efficiency, optimal regulation should seek to secure allocative efficiency, where the mix of local services provided must coincide with local community preferences, and productive efficiency, where local services must be produced in the most cost effective manner. In addition, regulation should also try to ensure that equity objectives are met. For example, essential local services should be provided to poor households by local councils at affordable prices. The effective application of regulation is difficult in all spheres of economic activity, including the operation of the local 
government sector (Bos 1994). Moreover, regulation is further complicated in the local government sphere due to the fact that local councils possess the legal authority to tax; a monopoly power missing in both the private sector and in most other public utilities. Finally, in the special case of local council revenue regulation through rate-pegging, the regulatory agency faces additional problems since it is not regulating the prices of particular local services but rather the 'tax-price' of a whole genre of local public goods and services that are mostly unpriced.

Against this background, IPART (2008:55) has summarised the arguments surrounding rate-pegging that have been employed in the NSW debate. In terms of the case for ratepegging, four separate arguments are identified:

a) Revenue regulation through rate-pegging prevents the abuse of monopoly power in the provision of basic local services;

b) Rate-pegging assists in controlling 'cross-subsidisation' and imposes restrictions on the 'provision of non-core services and infrastructure that might prove unsustainable to ratepayers';

c) Rate-pegging manages the risk of poor governance in the local government sector; and

d) Rate-pegging limits the ability of councils to divert funds from essential infrastructure to other projects as well as expenditure on 'marginal services' that are better provided by the private sector.

Some of these arguments are less than convincing. For example, it is not at all obvious that rate-pegging can have any positive influence on the supply of local services under argument (a); indeed it seems more likely to curtail their supply by restricting funding. Similarly, in terms of (b), it hard to appreciate why rate-pegging will dampen crosssubsidisation. Quite the opposite may occur if fees and charges are increased to counteract the impact of rate-pegging. Along analogous lines, argument (b) does not meet with empirical reality regarding 'non-core' local services. For instance, Dollery, Wallis and Allan (2006) have demonstrated that an ongoing shift in all Australian local government jurisdictions has taken place away from 'services to property' towards 'services to people', including NSW. Much the same objection can be levelled against 
argument (d). The NSW Treasury (2008:13-14) also found all four arguments largely unconvincing.

An additional argument for rate-pegging is adduced later in Revenue Framework for Local Government: Issues Paper (IPART2008:63). This contends that local government accountability is improved through rate-pegging because 'the process of assessing and making determinations on applications for special variation' ensures that the 'reasonableness of all applications is scrutinised' which may 'enhance councils' accountability'. But this argument is partly undermined by that fact that only a small proportion of NSW councils - only 26 councils out of 155 local authorities in 2008/09 (IPART 2008:56, Table 7.3) - actually applied for special variation; a point taken up later in this paper.

Two further implied arguments for rate-pegging were put forward in the Independent Inquiry into the Financial Sustainability of NSW Local Government (Allan et al 2006). Firstly, rate-pegging had worked well, compared with other Australian local government jurisdictions, if its primary aim was to constrain rises in council rates; an observation supported by both the Productivity Commission (2008) and the NSW Local Government and Shires Association (2008), which we will examine more closely in this paper. Secondly, rate-pegging may have forced NSW local government to become more efficient than it would otherwise have been, especially in the domain of corporate overheads and administrative costs (Allan et al 2006:245-257).

An alternative public choice argument for rate-pegging has been advanced by Dollery, Crase and Byrnes (2006). Invoking Wittman's (1995) model of democratic efficiency, they asserted that the pervasive nature of the phenomenon of 'local government failure' in Australian local government meant that electors had demanded state government oversight of local councils, especially in pecuniary affairs. Thus, in Australian states, “"watchdog” institutions will form an agency relationship with local government voters to demystify fiscal illusion by monitoring council revenue and expenditure decisions on behalf of voters (Dollery, Crase and Byrnes 2006:350). In NSW, this 'watchdog' role has occurred inter alia in the form of rate-pegging, which has enjoyed strong public support (see IRIS Research 2005). 
IPART (2008:55) identified four separate arguments employed in the debate against the use of rate-pegging:

a) Rate-pegging limits councils' ability to provide local services;

b) Rate-pegging prevented infrastructure backlogs from being addressed;

c) Rate-pegging led councils to impose higher user pays charges which could result in pricing inequities; and

d) Rate-pegging contradicts the principles of democracy and accountability of local government.

Most of these arguments seem to carry weight. In particular, argument (c) appears especially convincing. In this regard, the NSW Treasury (2008: 14) has noted that 'constraints on general revenue distort revenue raising sources and result in higher user charges'. Argument (a) also seems valid. After all, if the net effect of rate-pegging has indeed been to constrain total council income, then it follows that it must have limited local services as well. Argument (d) rests on normative grounds rather than on economic observation; it would appear obvious that regulation of rate-setting must diminish local democratic autonomy since it arbitrarily limits local decision making.

However, argument (b) does not meet available empirical evidence. For instance, the PriceWaterhouseCoopers (2006) National Financial Sustainability Study of Local Government found that not only was a large number of local councils in all Australian local government jurisdictions financially unsustainable in the long run, but that most councils confronted a massive local infrastructure backlog, regardless of the rate-setting regime in each state. Moreover, Byrnes, Dollery, Crase and Simmons (2008), Dollery, Byrnes and Crase (2007), and others, have demonstrated that the magnitude of this backlog is so substantial that it is now beyond the present capacity of any Australian local government system to remedy without outside financial intervention. Since this problem is endemic to all Australian jurisdictions, and does not appear to be comparatively more acute in NSW, it would thus seem that the NSW local infrastructure backlog cannot be ascribed simply to rate-pegging. The abolition of rate-pegging in NSW cannot therefore be expected address this problem.

The Local Government and Shires Associations of NSW (2008) developed a further and more general argument against rate-pegging couched in political economy terms. One 
aspect of this argument is that rate-pegging has an unintended and broader 'dampening' effect on rates than simply the pegged limit. In this vein, the Association (2008: 14) contended that 'one likely explanation for the dampening effect is that rate-pegging provides a public framework and creates public expectations about maximum rate increases, placing political pressure on councils to stay within the limit and not seek special variations'. A second dimension of this general argument is that rate-pegging provides a useful mechanism for local councils in NSW to engage in politically expedient 'blame shifting' onto the state government. The Association (2008: 15) argued that rate-pegging 'provides an easy default option from both a political and managerial perspective' since (a) all rate increases can be attributed to the state government; (b) the need for community consultation to justify rate rises diminishes; (c) sticking to the ratepeg limit avoids the problems contingent on special variation applications; (d) 'councils can blame the state government for their financial deficiencies'; and (e) the existence of rate-pegging enables councils to avoid long-term planning. The net result of these factors has been the 'under-provision of community infrastructure and services', the emergence of a local infrastructure backlog and 'undermining' the financial sustainability of councils.

\section{Impact of Rate-Pegging}

The impact of rate-pegging on the NSW local government sector is best assessed not in isolation, but rather in comparison with the experience of local government systems in other Australian state jurisdictions which do not have any regulatory ceiling imposed on rate increases. In other words, the unique use of rate-pegging in NSW allows analysts to treat it as a kind of 'natural experiment' in Australian local government. A comparative exercise of this kind faces several difficulties, quite apart from the ubiquitous problem of data comparability. The most important of these difficulties in the present context are twofold:

First, there are substantial differences in relative significance of different sources of revenue in the different states (Worthington and Dollery 2001; 2002). For example, IPART (2008: 25) observed that 'there tends to be an inverse relationship between taxation revenue and revenue obtained from the sale of goods and services'. Thus 'states with greater reliance on taxation revenue (South Australia (57.9 per cent), Victoria (47.2 per cent), and Western Australia (43.5 per cent)) collected less revenue from the sale of 
goods and services, whereas states with less reliance on taxation revenue (Tasmania (32.2 per cent) and Queensland (26.0 per cent)) obtained greater revenue from the sale of goods and services'. By contrast, the NSW local government sector 'is close to average, with a relatively even split in terms of its reliance on either revenue source'. However, in the present context, this problem is ameliorated by the fact that we are not concerned with absolute differences in the level of rates between NSW and other state local government jurisdictions, but rather in the rates of change in property tax revenue through time.

Second, considerable variation exists in the functions of local government in the different jurisdictions (Worthington and Dollery 2001 2002), which affect both expenditure and revenue patterns. For instance, in Queensland, Tasmania and non-metropolitan NSW (outside of the greater Newcastle-Sydney-Wollongong conurbation served by Sydney Water and Hunter Water), councils provide sewerage and water supply services, which earn an income, in contrast to the other state local government jurisdictions. In addition, there is an ongoing shift in local government functions away from 'services to property' towards 'services to people' (Dollery, Wallis and Allan 2006), which further distorts comparison; unless it is heroically assumed that this shift has occurred in a uniform manner across all states. However, because we are chiefly concerned with trends through time in rate rises, both of these problems become less acute.

These variations are compounded by the fact that large disparities in the capacities of individual local councils to raise rate revenues also exist within given state jurisdictions, as vividly illustrated in the Productivity Commission's (2008) Assessing Local Government Revenue Raising Capacity, especially Table 3.1 in this Report. While these disparities are in part attributable to the socio-economic characteristics of different local government areas, particularly local disposable incomes and their impact on the ability of householders to pay rates, numerous other influences are obviously at play, notably 'differences between urban, rural and remote councils, in population, rating base and the ability or willingness of councils to levy user charges’ (DOTARS 2007: 12).

With these caveats in mind, we now seek to determine the impact of rate-pegging in NSW local government in the larger Australian local government context. Figure 2 
illustrates trends in local government rate revenue per capita by state and territory jurisdiction over the period 1998/99 to 2005/06, expressed in constant 1998/99 dollars.

Figure 2: Local Government Rate Revenue per Capita, 1998/99 to 2005/06

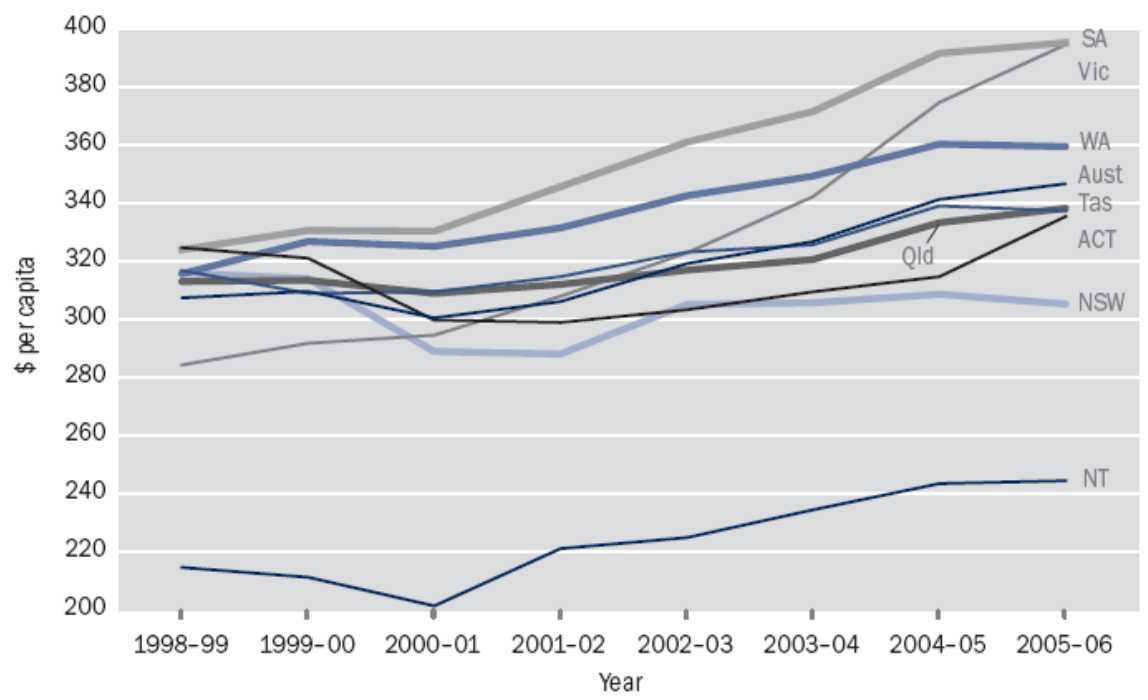

Source: DOTARS, 2007, p. 15.

A glance at Figure 2 demonstrates that the average per capita rate revenue funding gap between NSW and the other Australian jurisdictions has grown over the seven-year period in question. Furthermore, it is noteworthy that NSW also has 'the lowest council rates per capita of any jurisdiction in Australia other than the Northern Territory' (Allan et al 2006: 207). Similar insightful data have been assembled by Allan et al (2006: 207, Table 9.4), reproduced here in Table 1 (which reinforce the information in Figure 2).

Table 1: Total Percentage Rate Increases by Jurisdiction, 1995/96 to 2003/04

\begin{tabular}{c|c}
\hline State or territory & Per cent increase \\
\hline NSW & $29.2 \%$ \\
\hline ACT & $35.2 \%$ \\
\hline Tasmania & $36.3 \%$ \\
\hline South Australia & $55.1 \%$ \\
\hline Queensland & $55.6 \%$ \\
\hline Western Australia & $64.8 \%$ \\
\hline Victoria & $66.1 \%$ \\
\hline Gross domestic product & $61.8 \%$ \\
\hline
\end{tabular}


It is evident from Table 2 that the percentage increase in rates was substantially lower in NSW than in the other states; indeed, it amounted to less than half of the rate rises experienced in Western Australia and Victoria. From this and other data, Allan et al (2006: 2007) concluded that 'rate-pegging has been a constraint on [NSW] councils' revenue-raising capacity causing it to fall behind other states, notwithstanding NSW's relatively strong property market over this period compared with Australia as a whole'. The Productivity Commission (2008: xxxiii-xxxiv) drew very similar conclusions from its deliberations. After stressing that 'the rate of growth in rates revenue in NSW has been among the lowest of all jurisdictions over the past seven years', it noted that NSW 'also has rate revenue per person below that of most other jurisdictions'. It thus found that 'rate-pegging in NSW appears to have been restricting revenue raised from rates, notwithstanding scope for councils to seek variations to mandated rate increases'. The Local Government and Shires Associations of NSW (2008: 14) reached an analogous conclusion: 'If the objective of rate-pegging was simply to constrain council rate revenues, rate-pegging has been a success' since 'NSW rate revenue growth is lagging other jurisdictions'.

In addition, as we have seen, the Associations (2008:14) contended that rate-pegging had several other unintended effects. They asserted that rate-pegging has reduced investment in infrastructure maintenance and renewal - an argument which does not appear to accord with the evidence garnered by PriceWaterhouseCoopers (2006). A much more important argument in the present context resides in their claim that the special variation option is under-utilised, which suggests that the rate-pegging system has had a more general 'dampening' effect than the stipulated rate peg itself.

This proposition is worth considering in more detail. Table 2 provides information on the number of special variation applications submitted over the past seven years and the number of these applications that were approved by the Minister. 
Table 2: Total Special Variation Applications Submitted and Approved, 2002/03 to 2008/09

\begin{tabular}{|c|c|c|c|c|c|c|c|c|}
\hline & $2002 / 03$ & $2003 / 04$ & $2004 / 05$ & $2005 / 06$ & $2006 / 07$ & $2007 / 08$ & $2008 / 09$ & $2009 / 10$ \\
\hline $\begin{array}{l}\text { Rate peg } \\
\text { percentage }\end{array}$ & 3.3 & 3.6 & 3.5 & 3.5 & 3.6 & 3.4 & 3.5 & 2.6 \\
\hline $\begin{array}{l}\text { Number of } \\
\text { applications } \\
\text { for special } \\
\text { variation } \\
\text { received }\end{array}$ & 30 & 23 & 25 & 42 & 46 & 34 & 30 & 28 \\
\hline $\begin{array}{l}\text { Number of } \\
\text { applications } \\
\text { for special } \\
\text { variation } \\
\text { approved }\end{array}$ & 23 & 23 & 22 & 30 & 39 & 30 & 18 & $\mathrm{~N} / \mathrm{A}$ \\
\hline $\begin{array}{l}\text { Total } \\
\text { number of } \\
\text { Councils }\end{array}$ & 172 & 172 & 152 & 152 & 152 & 152 & 152 & 152 \\
\hline
\end{tabular}

Source: IPART (2008: 56); Allan et al (2006: 50): pers. comm. Mark Hely, Principal Finance Officer, NSW Division of Local Government, Premier’s Department, 17.06.10

The information contained in Table 2 seems to vindicate the observations made by the NSW Local Government and Shires Association (2008), considered earlier in this paper, regarding the broader 'dampening' effects of rate-pegging. Thus in the 2008/09 special variation round, only 26 councils applied - a mere 17 per cent of all councils - of which 24 were successful. Put differently, while only a small proportion of councils actually apply under the special variation system, a very high faction of these applications prove successful, ranging from a low of 71 per cent in the 2005/06 round to a high of 100 per cent in 2003/04. In other words, even though the great majority of special variation applications are approved by the Minister, comparatively few local authorities apply; a fact which thus must be ascribed to factors other than the prospects of success of an application. 
A final aspect of special variations is their net effect on aggregate increases in rates in NSW local government through time. Figure 2 compares the long-term trends in the ratepeg with actual outcomes after special variations had been approved.

Figure 2: Growth in Actual Rates Relative to Pegged Rates, 1995/96 to 2003/04

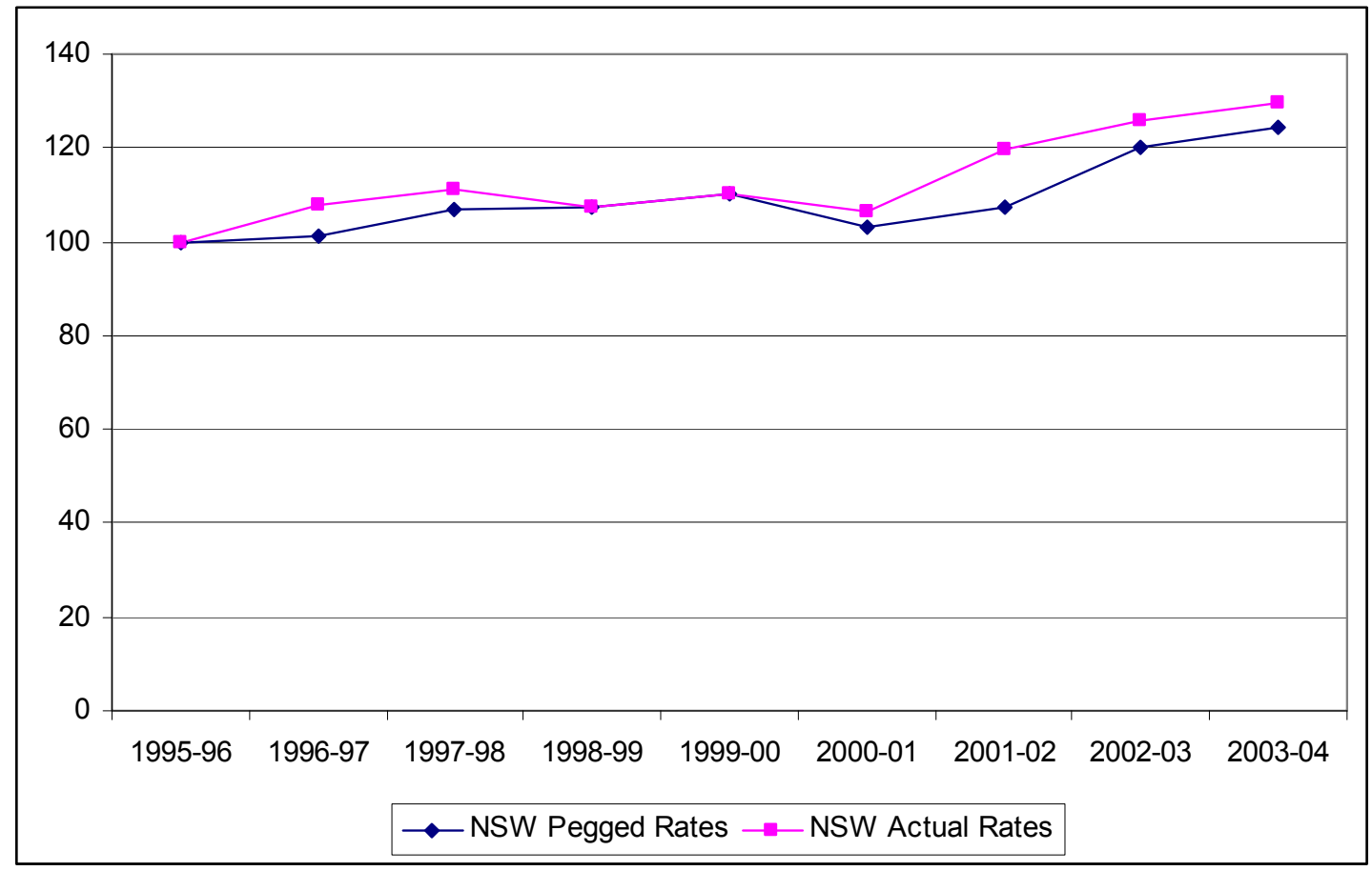

Source: Amended Figure 9.7, Allan Report (2006, Figure 9.7, p.208)

The data contained in Figure 2 demonstrate that the impact of special variations on actual outcomes is minor; the observed final growth of rates diverges minimally from the ratepegged trend line. Allan et al (2006: 207) drew the same general conclusion: 'additional revenue allowed' as a consequence of the special variation system has 'not been large as a proportion of the total increase in the rate peg limit'.

\section{Suggested Improvements to NSW Rate-Setting}

Over the years there has been no shortage of suggestions on how to improve the operation of rate-setting in NSW. For example, a Rate Pegging Taskforce, established by the NSW Local Government and Shires Associations in 2001, called for a 'compromise' two-tiered rate-pegging system (Centennial Consultancy, 2004). Tier 1 would employ an annually determined index of local government costs, which would apply to all NSW councils, which would accurately reflect the real costs impinging on local councils much 
more precisely than the CPI used at present. Tier 2 would replace the current special variation system with a method that took the circumstances of individual councils into account and allow councils to make their own variations above Tier 1 levels up to some stipulated maximum.

Allan et al (2006: 210) also presented a 'compromise' proposal to revise the rate-pegging system. This Report argued that 'the view of this Inquiry is that the peg should be made less discretionary (i.e. not subject to Ministerial fiat), be based on explicit criteria (e.g. local government unit costs), and be made more transparent (i.e. be published in full). Moreover, 'any variations to the peg with respect to a particular council should be more fully disclosed and explained in terms of rational criteria that are applied consistently across all councils and not subject to capricious change'.

At a more general level, in its Revenue Framework for Local Government, IPART (2008: 63-65) presented five alternative regulatory frameworks that could replace the current rate-pegging system. A detailed evaluation of these options falls outside the scope of this paper and would require empirical simulation exercises using 'realistic' data on particular types of local authorities to try to model their characteristics and impact of the alternative regulatory frameworks. However, it is nonetheless worth briefly outlining these possibilities. Option 1 would retain existing rate-pegging arrangements, but publish the economic basis for the peg, modify the special variations process, and leave all other charges unregulated. Option 2 would develop a more 'disaggregated form of ratepegging' using specific pegs for specific categories of council. Option 3 would 'reduce the scope of rate-pegging to cover only local government revenue needed to fund operating expenditure', thereby excluding capital expenditure and all other charges unregulated. Option 4 would retain rate-pegging but exempt individual councils, provided they could demonstrate financial prudence and operational efficiency in various stipulated ways. Finally, Option 5 would remove mandatory rate-pegging and simultaneously 'enhance accountability to the local community' using several criteria and the threat of a 'default rate cap'.

A detailed analysis of the characteristics of these five options has been conducted by the NSW Treasury (2008). It has also suggested several additional feasible approaches to NSW council rates regulation. Amongst all these alternative regulatory methods, the 
NSW Treasury (2008: 27) argued that the objectives of the current NSW rate-pegging regime could best be achieved at the least cost by retaining the existing rate-pegging system, but with 'improved criteria’.

Given the historical reluctance of the NSW state governments to make significant changes to the rate-pegging system, and the current NSW Government's new 'minimalist' modifications to the rate-pegging process, it would seem that these suggested reforms will remain hypothetical.

\section{Concluding Remarks}

Against the background of the IPART (2009) Review of the Revenue Framework for Local Government, this paper has considered the nature of rate-pegging, the arguments surrounding its desirability, and its economic effects on NSW local government. We have seen that the case for rate-pegging seems to hinge only on three convincing arguments. In the first place, as we have demonstrated in this paper, rate-pegging has achieved its basic objective of slowing increases in NSW council rates over time relative to other Australian jurisdictions (Allan et al 2006). Secondly, a prima facie case exists which suggests that the constraints imposed on council revenue by rate-pegging may have enhanced the administrative efficiency of NSW councils and reduced their overheads, at least in comparison with the NSW state government departments (Allan et al 2006). Finally, rate-pegging has enjoyed ongoing and strong public support (IRIS Research 2005), which appears to demonstrate the operation of an efficient 'political market' in NSW (Dollery, Crase and Byrnes 2006: 397) in the Wittman (1995) sense.

By contrast, several cogent arguments have been advanced against rate-pegging. Firstly, it has depressed the rating effort by NSW councils more than it intended since it has had a broader 'dampening' impact on rates in particular and local government finance more generally due to the limited use of the special variation option. Secondly, the existence of rate-pegging has partly absolved local councils of full responsibility for their own financial affairs, with numerous deleterious consequences, not least a lack of long-term planning, which is an essential part of the new IPR framework within which NSW local government must operate from the fiscal year 2010/11 onwards. Finally, rate-pegging has undermined the democratic bedrocks of 'local voice' and 'local choice' in local government and thereby reduced local autonomy. 
The reluctance of the NSW Government to both release the Final Report of Review of the Revenue Framework for Local Government and to formally respond to its recommendations, as well as its recent decision to retain rate-pegging but shift the process to IPART, suggests that, despite the announcement by (former) NSW Premier Rees that the NSW government had considered the abolition of rate-pegging, ratepegging seems set to continue in NSW, albeit in a slightly amended form. Moreover, its continuing popularity seems to indicate that, at best, marginal efforts will be made to improve the operation of rate-pegging and thereby at least ameliorate some of its harmful effects, rather than abolish it.

\section{References}

Allan, P et al (2006) Are Councils Sustainable: Final Report and Recommendations, Inquiry into the Financial Sustainability of NSW Local Government, NSW Local Government and Shires Associations, Sydney.

Bailey, S. J. (1999) Local Government Economics: Principles and Practice, Macmillan, London.

Bos, D. (1994) Pricing and Price Regulation, Elsevier North Holland, Amsterdam.

Byrnes, J., Dollery, B. E., Crase, L. and Simmons, P. (2008) 'Resolving the Infrastructure Crisis in Local Government: A Bond Market Issue Approach Based on Local Council Income', Australasian Journal of Regional Studies, 14(2), pp. 115-131.

Centennial Consultancy (1994) NSW Rate-pegging: Refining the SVA Process: Report Prepared for the NSW Local Government and Shires Associations, NSW Local Government and Shires Association, Sydney.

Department of Local Government (2007) Council Rating and Revenue Raising Manual, NSW Department of Local Government, Sydney.

Department of Transport and Regional Services (DOTARS) (2007) 2005/06 Local Government National Report, DOTARS, Canberra.

Dollery, B.E., Byrnes, J.D. and Crase, L (2007) 'The Infrastructure Crisis in Australian Local Government: A proposed Federal Asset Fund Solution’, Australasian Journal of Regional Studies, 13(1), pp. 3-19.

Dollery, B. E., Crase, L. and Byrnes, J. L. (2006) 'Local Government Failure: Why Does Australian Local Government Experience Permanent Financial Austerity?’, Australian Journal of Political Science, 41(3), pp. 395-409.

Dollery, B. E., Crase, L. and Johnson, A. K. (2006) Australian Local Government Economics, UNSW Press, Sydney.

Dollery, B. E., Wallis, J. L. and Allan, P. (2006) 'The Debate That Had to Happen But Never Did: The Changing Role of Australian Local Government', Australian Journal of Political Science, 41(4), pp. 553-567.

Figlio, D. N. and O'Sullivan, A. (2001) 'The Local Response to Tax Limitation Measures: Do Local Governments Manipulate Voters to Increase Revenues?’, Journal of Law and Economics, 44(1), pp. 233-257. 
Hillman, A. L. (2005) Public Finance and Public Policy, Cambridge University Press, Cambridge.

Independent Pricing and Regulatory Tribunal (IPART) (2008) Revenue Framework for Local Government: Issues Paper, IPART, Sydney.

Independent Pricing and Regulatory Tribunal (IPART) (2009) Draft Review of the Revenue Framework for Local Government, IPART, Sydney.

IRIS Research (2005) 'Opinion Poll of Local Government in NSW', in Allan, P et al (2006) Are Councils Sustainable: Final Report and Recommendations, Volume Two, Inquiry into the Financial Sustainability of NSW Local Government, NSW Local Government and Shires Associations, Sydney.

Johnson, A. K. (2001) Beyond the Three R's: Financing Local Government, Centre for Local Government, University of New England.

Keneally, K. (2010) 'Significant Reform to Local Council Infrastructure Charges', News Release, Premier’s Department, NSW Government, Sydney, 4 June, pp.1-3.

Local Government and Shires Associations of NSW (2008) Submission to the Independent Pricing and Regulatory Tribunal of NSW's Review of Revenue Framework for Local Government, Local Government and Shires Associations of NSW, Sydney.

NSW Treasury (2008) Submission to the NSW Independent Pricing and Regulatory Tribunal, NSW Treasury, Sydney.

PriceWaterhouseCoopers (2006) National Financial Sustainability Study of Local Government, Australian Local Government Association, Canberra.

Productivity Commission (2008) Assessing Local Government Revenue Raising Capacity, Productivity Commission Research Report, Canberra.

Radbone, I. and Robins, J. R. (1980) ‘Australian Local Government and Responsibility’, Australian Journal of Political Science, 15(2), 1980, pp. $204-213$.

Temple, J. A. (1996) 'Community Composition and Voter Support for Tax Limitations: Evidence from Home-rule Elections’, Southern Economic Journal, 62(4), pp.1002-1016.

Vigdor, J. L. (2004) 'Other People's Taxes: Non-resident Voters and State-wide Limitation of Local Government’, Journal of Law and Economics, 47(2), pp. 453-476.

Wittman, D. (1995) The Myth of Democratic Failure: Why Political Institutions are Efficient, University of Chicago Press, Chicago.

Worthington, A. C. and Dollery, B. E. (2001) 'Diversity in Australian Local Government: The Case Against the Imposition of National Uniform Standards', International Review of Public Administration, 6(1), pp. 49-58.

Worthington, A. C. and Dollery, B. E. (2002) 'An Analysis of Recent Trends in Australian Local Government’, International Journal of Public Sector Management, 15(6), 496-515. 